\title{
Spontaneous tumour lysis syndrome in a case of multiple myeloma - A rare
}

\author{
occurrence
}

Kavitha Saravu ${ }^{1}$, Suresh Kumar ${ }^{1}$, Ananthakrishna Barkur Shastry ${ }^{1}$, Annamma Kurien ${ }^{2}$, Ravindra

\author{
Prabhu $^{3}$, Rishikesh Kumar ${ }^{1}$
}

1. Department of Medicine, Kasturba Medical College, Manipal University, Manipal, Karnataka, India

2. Department of Pathology, Melaka Manipal Medical College, Manipal University, Manipal, Karnataka, India

3. Department of Nephrology, Kasturba Medical College, Manipal University, Manipal, Karnataka, India

\section{CASE REPORT}

Please cite this paper as: Saravu K, Kumar S, Shastry BA, Annamma K, Prabhu R, Rishikesh K. Spontaneous tumour lysis syndrome in a case of multiple myeloma - $A$ rare occurrence. AMJ 2013, 6, 3, 168-171. http//dx.doi.org/10.4066/AMJ.2013.1592

Corresponding Author:

Kavitha Saravu

Medicine OPD Room No. 17, Kasturba

Hospital, Manipal University, Manipal,

Karnataka-576104, India.

E-mail: kavithasaravu@gmail.com

\section{Abstract}

We describe a case of a 40-year-old male patient who was found to have multiple myeloma with spontaneous tumour lysis syndrome (TLS), following a compression fracture of the L-2 vertebrae. Multiple myeloma was confirmed by bone marrow analysis and the $\mathrm{M}$-band on serum protein electrophoresis. Hyperuricaemia (26.2 $\mathrm{mg} / \mathrm{dL})$, hyperkalaemia (> $7.0 \mathrm{mEq} / \mathrm{L}$ ), hyperphosphatemia (16.2 mg of phosphorus/dL), normocalcemia and acute kidney injury, prior to anticancer treatment suggested spontaneous TLS. Inciting events for tumour lysis, such as chemotherapy, dehydration and exposure to steroids were absent. Patient received hydration, hypourecemic drugs and haemodialysis. This case report highlights the rare presentation of multiple myeloma with spontaneous TLS.

\section{Key Words}

Hyperphosphatemia, hyperkalaemia, hyperuricaemia, normocalcaemia, renal failure,

\section{Implications for Practice}

- Spontaneous tumour lysis syndrome (STLS) is a rare occurrence in multiple myeloma and, to our knowledge; this is the first such case being reported.

- The absence of inciting events for tumour lysis such as chemotherapy, dehydration and exposure to steroids were suggestive of STLS.

- It is important to recognise the possibility of tumour lysis prior to initiation of treatment as it is life-threatening and constitutes an oncological emergency.

\section{Background}

Spontaneous tumour lysis syndrome (STLS) is a rare oncologic emergency resulting in disturbed homeostasis from an unknown aetiology which occurs prior to anticancer treatment. STLS is characterised by hyperuricaemia, hyperkalaemia, secondary hypocalcaemia, metabolic acidosis, acute renal failure and absence of hyperphosphatemia. ${ }^{1}$ Occurrences of STLS have been documented in settings of leukaemia, lymphoma and solid tumours $^{2,3}$ and have been associated with worse outcomes. We report a case of a middle aged male with multiple myeloma presenting with STLS. To our knowledge, this is the first case of STLS being reported in multiple myeloma.

\section{Case details}

A 40-year-old male cultivator presented with extreme fatigue, vomiting, breathlessness and decreased urine output for last one day. Examination showed pallor, tachycardia, blood pressure $(130 / 70 \mathrm{~mm} \mathrm{Hg})$, respiratory rate $(28 / \mathrm{min})$ and $\mathrm{SpO}_{2}$ on room air (76\%), bibasilar lung crepitations and moderate splenomegaly. Arterial blood gas analysis showed metabolic acidosis and hypoxia. A chest radiograph was suggestive of pulmonary oedema. Table 1 summarises the relevant laboratory tests done. 
Table 1. Laboratory tests result before and after STLS development

\begin{tabular}{|c|c|c|c|c|}
\hline $\begin{array}{l}\text { Test } \\
\text { parameters/ } \\
\text { Results }\end{array}$ & $\begin{array}{l}\text { Pre - } \\
\text { admis- } \\
\text { sion } \\
\text { (One } \\
\text { week) }\end{array}$ & $\begin{array}{l}\text { On } \\
\text { admi- } \\
\text { ssion }\end{array}$ & $\begin{array}{l}\text { On } \\
\text { discha- } \\
\text { rge }\end{array}$ & $\begin{array}{l}\text { Reference } \\
\text { range }\end{array}$ \\
\hline $\begin{array}{l}\text { Haemoglobin } \\
\text { (gm/dL) }\end{array}$ & 8.9 & 7.8 & 8.6 & $13-18$ \\
\hline $\begin{array}{l}\text { Platelet count } \\
\text { (cells } / \mathrm{mm}^{3} \text { ) }\end{array}$ & 12000 & 11000 & 22,000 & $\begin{array}{l}1,50,000- \\
4,00,000\end{array}$ \\
\hline $\begin{array}{l}\text { Total WBC } \\
\text { (cells } / \mathrm{mm}^{3} \text { ) }\end{array}$ & 5500 & 8500 & 18,700 & $\begin{array}{l}4,000- \\
10,000\end{array}$ \\
\hline $\begin{array}{l}\text { Erythrocyte } \\
\text { sedimentation } \\
\text { rate }(\mathrm{mm} / 1 \mathrm{st} \mathrm{hr} \text { ) }\end{array}$ & 140 & 145 & NA & $0-15$ \\
\hline $\begin{array}{l}\text { Total serum } \\
\text { protein (gm/dL) }\end{array}$ & 9.4 & 8.7 & 11.0 & $6-8$ \\
\hline $\begin{array}{l}\text { Serum albumin } \\
\text { (gm/dL) }\end{array}$ & 3.2 & 2.7 & 2.9 & $3.5-5.0$ \\
\hline $\begin{array}{l}\text { Serum globulin } \\
\text { (gm/dL) }\end{array}$ & 6.2 & 6.0 & 8.1 & $1.8-3.4$ \\
\hline $\mathrm{A} / \mathrm{G}$ ratio & 0.51 & 0.45 & 0.36 & $0.8-2.0$ \\
\hline $\begin{array}{l}\text { Blood urea } \\
(\mathrm{mg} / \mathrm{dL})\end{array}$ & 41 & 270 & 106 & $8-35$ \\
\hline $\begin{array}{l}\text { Serum creatinine } \\
(\mathrm{mg} / \mathrm{dL})\end{array}$ & 1.4 & 9.4 & 3.4 & $0.6-1.6$ \\
\hline $\begin{array}{l}\text { Serum } \\
\text { potassium } \\
(\mathrm{mEq} / \mathrm{L}) \\
\end{array}$ & 4.1 & $>7.0$ & 3.8 & $3.5-5.0$ \\
\hline $\begin{array}{l}\text { Serum sodium } \\
(\mathrm{mEq} / \mathrm{L})\end{array}$ & 137 & 128 & 136 & $130-143$ \\
\hline $\begin{array}{l}\text { Serum lactate } \\
\text { dehydrogenase } \\
(\mathrm{U} / \mathrm{L})\end{array}$ & 430 & 980 & NA & $125-250$ \\
\hline $\begin{array}{l}\text { Serum uric acid } \\
(\mathrm{mg} / \mathrm{dL})\end{array}$ & 6.9 & 26.2 & 7.8 & $4.4-7.6$ \\
\hline $\begin{array}{l}\text { Serum calcium } \\
(\mathrm{mg} / \mathrm{dL})\end{array}$ & 9.8 & 10.1 & 10.9 & $8.6-10.2$ \\
\hline $\begin{array}{l}\text { Serum } \\
\text { phosphate (mg } \\
\text { of } \\
\text { phosphorus/dL) }\end{array}$ & NA & 16.2 & 8.2 & $2.5-4.5$ \\
\hline
\end{tabular}

NA: Not available

The patient had reported to us one week before admission with a two-week history of fever, fatigue, low backache, a healed herpes zoster lesion (D4 dermatomal distribution in the right chest), gross pallor, moderate splenomegaly and mild hepatomegaly. A preliminary evaluation showed prerenal azotemia, the 'M-band' on serum protein electrophoresis and raised IgG immunoglobulin (5835 $\mathrm{mg} / \mathrm{dL}$ ) levels. A radiograph of the lumbar spine showed a compression fracture of the $L-2$ vertebrae (Figure 1 ). Bone marrow aspiration and trephine biopsy was performed and sent for cytology evaluation. While pending his laboratory reports, he was prescribed amitriptyline and paracetamol for pain relief.

\section{Figure 1: X-ray lumbosacral spine showing compression fracture of $L-2$ vertebra}

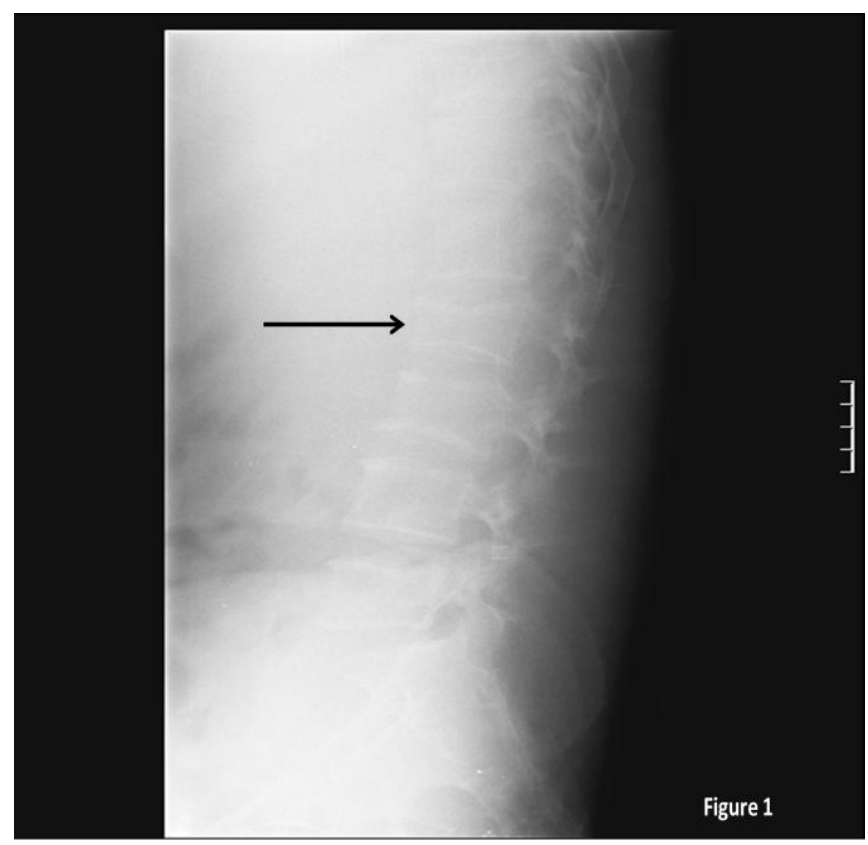

A peripheral blood smear showed leukoerythroblastic picture with abnormal plasma cells and plasmacytoid lymphocytes. Bone marrow aspirate, imprint smear and trephine biopsy reported clusters of abnormal cells comprising of abnormal lymphoid cells (nuclear cleaving, lobation and other irregularities), plasmacytoid lymphocytes, abnormal plasma cells \& plasmablasts (Figure 2). Normal erythroid and myeloid elements were markedly suppressed. Immunohistochemistry examinations revealed: CD138 - strong positive, myeloperoxidase (MPO) negative, CD117 - negative and CD3 - negative. Flow cytometric analysis showed $89.60 \%$ B - cells expressing cytoplasmic $\lambda$ (cy $\lambda$ ) - light chains. A bone scan done in view of bone pain showed osteoblastic lesions in D4, D11, L2 and L3 vertebrae. On admission, serum $\beta-2$ microglobulin level was reported to be $22,370.30 \mathrm{mg} / \mathrm{dL}$. A diagnosis of multiple myeloma stage IIA was made as per the Durie-Salmon staging system. ${ }^{4}$ 
Figure 2: Leishman's stained bone marrow smear showing: (1) plasma cell, (2) small lymphocyte and (3) plasmalymphocytic cell with enhanced rouleaux formation in the background, at 100x magnification

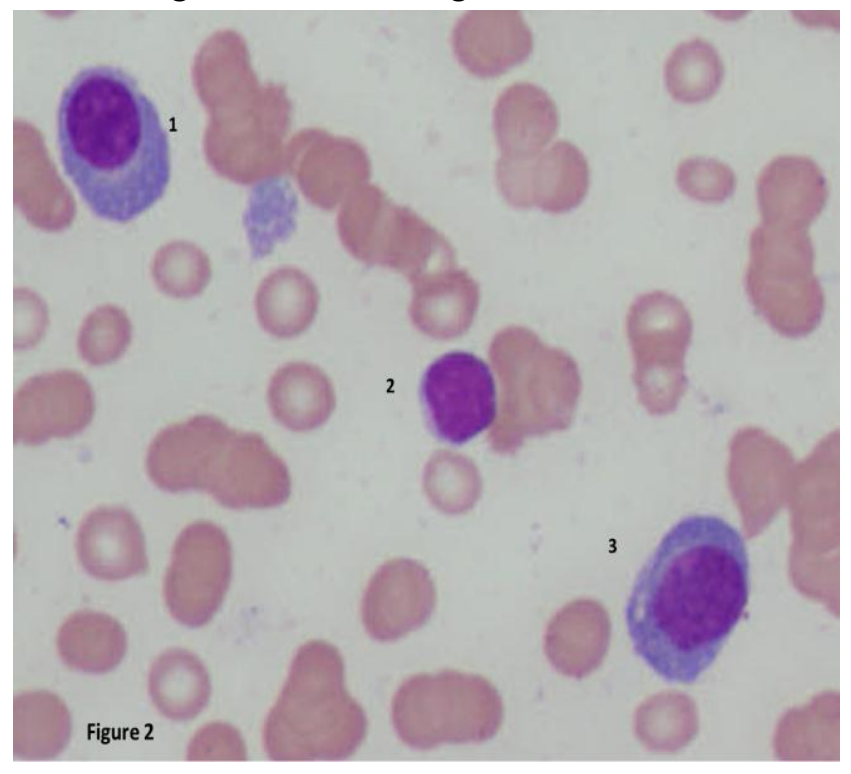

In view of severe hyperkalaemia, hyperuricaemia, normocalcemia, hyperphosphatemia and acute kidney injury (Table 1 ) before administration of anticancer chemotherapy, a diagnosis of STLS was made. He received anti-hyperkalaemic measures, the hypouricaemic drug 'allopurinol' $600 \mathrm{mg} /$ day orally (300 mg/m $/$ day) and intravenous hydration. Haemodialysis was initiated with clinical improvement. After three sessions, blood urea (69 $\mathrm{mg} / \mathrm{dL}$ ) and serum creatinine $(3.4 \mathrm{mg} / \mathrm{dL}$ ) levels improved over 15 days. Palliative radiotherapy at a dose of $30 \mathrm{~Gy}$ over 10 fractions was initiated for the compression fracture of the $L-2$ vertebrae, but stopped after the fourth exposure because of severe thrombocytopenia, leukocytosis and hyperbilirubinemia. At this stage, the patient took discharge against medical advice.

\section{Discussion}

TLS is a life-threatening, rare conformation of metabolic disturbances occurring in about $5-20 \%$ of all malignancies. ${ }^{5}$ Precise information about the epidemiology of spontaneous TLS is not available in literature and its occurrence in multiple myeloma setting has not been reported. Multiple myeloma at the age of 40 years or below, itself is a rare occurrence (about $2 \%$ ). ${ }^{6}$ The coincidence of two such rare medical complications makes this case unique and interesting.

A rise in serum uric acid $>15 \mathrm{mg} / \mathrm{dL}$ and serum phosphate $>$ $8 \mathrm{mg} / \mathrm{dL}$, along with acute kidney injury in patients with a large tumour burden should raise a suspicion of $\mathrm{TLS}^{1}{ }^{1}$ In acute kidney injury without TLS, serum uric acid and phosphate levels are found to be less than $12 \mathrm{mg} / \mathrm{dL}$ and 6 $\mathrm{mg} / \mathrm{dL}$ respectively. ${ }^{1}$ Disproportionately high levels of serum uric acid and phosphate levels of $26.2 \mathrm{mg} / \mathrm{dL}$ and 16.2 $\mathrm{mg} / \mathrm{dL}$ respectively seen in the present case were pointers towards underlying TLS.

Although the patient was diagnosed to have multiple myeloma, TLS was not an anticipated event since chemotherapy had not been started. The exact aetiology of STLS is not known till date, although an increased production of glucocorticoids and hyperthermia has been hypothesised to cause increased tumour lysis. ${ }^{2}$ However this explanation seems to be inappropriate in this setting of multiple myeloma and thorough research needs to be done to understand the aetiology of STLS in multiple myeloma.

Furthermore, the finding of hyperphosphatemia in this case is in contrast with the fact that it occurs only in posttreatment TLS and not in spontaneous/pre-treatment TLS. ${ }^{1}$ One of the obvious explanations for hyperphosphatemia seems to be a low mitotic rate of myeloma cells, which results in less reutilization of the released intracellular phosphate leading to its accumulation in the extracellular spaces following tumour lysis. High serum calcium level is usually seen in multiple myeloma condition which occurs due to an increased bone destruction rate. The normocalcaemia observed here may represent a balance between multiple myeloma causing hypercalcaemia and STLS causing secondary hypocalcaemia.

This case highlights the prompt recognition of STLS in multiple myeloma, which is extremely rare in tumours with an indolent course like multiple myeloma. It is important to be aware of the possibility of tumour lysis prior to initiation of treatment as it may lead to an oncological emergency. A high index of suspicion, prompt recognition and aggressive treatment with intravenous hydration, administration of hypourecaemic drugs like rasburicase or allopurinol and judicious haemodialysis are critical for successful outcome.

\section{References}

1. Solh M, Appel J. Tumour Lysis Syndrome. Hospital Physician 2008;44:25-9. http://www.turnerwhite.com/memberfile.php?PubCode=hp_sep08_lysis.pdf

2. Opyrchal M, Figanbaum T, Ghosh A, Rajkumar V, Caples S. Spontaneous tumour lysis syndrome in the setting of B-cell lymphoma. Case Rep Med. 2010;2010:610969.

3. Vaisban E, Braester A, Mosenzon O, Kolin M, Horn Y. Spontaneous tumour lysis syndrome in solid tumours: Really a rare condition? Am J Med Sci 2003;325:38-40.

4. Terpos E, Rahemtulla A. Myeloma. In: Postgraduate Haematology. Fifth edition. Edited by Hoffbrand AV, Catovsky D, Tuddenham EGD. Massachusetts, USA: 
Blackwell Publishing; 2005:681-701.

5. Tosi P, Barosi G, Lazzaro C, Liso V, Marchetti M, Morra E, Pession A, Rosti G, Santoro A, Zinzani PL, Tura S.. Consensus conference on the management of tumour lysis syndrome. Haematologica. 2008 Dec;93(12):1877-85.

6.Kyle RA, Gertz MA, Witzig TE, Lust JA, Lacy MQ, Dispenzieri A, Fonseca R, Rajkumar SV, Offord JR, Larson DR, Plevak ME, Therneau TM, Greipp PR. Review of 1027 patients with newly diagnosed multiple myeloma. Mayo Clin Proc. 2003 Jan;78(1):21-33.

\section{PEER REVIEW}

Not commissioned. Externally peer reviewed.

\section{CONFLICTS OF INTEREST}

The authors declare that they have no competing interests.

\section{FUNDING}

None

\section{PATIENT CONSENT}

The authors, Saravu Kavitha, Kumar Suresh, Shastry Barkur Ananthakrishna, Kurien Annamma, Prabhu Ravindra and Kumar Rishikesh declare that:

1. They have obtained written, informed consent for the publication of the details relating to the patient(s) in this report.

2. All possible steps have been taken to safeguard the identity of the patient(s).

3. This submission is compliant with the requirements of local research ethics committees. 